\title{
Efficiency of the photosynthetic apparatus in Cannabis sativa L. fertilized with sludge from a wastewater treatment plant and with phosphogypsum
}

\author{
Dariusz Zielonka ${ }^{1}$, Mariusz Nierebiński ${ }^{2}$, Hazem M. Kalaji ${ }^{3}$, Janusz Augustynowicz ${ }^{2}$, \\ Anna Prędecka ${ }^{4}$, Stefan Russel ${ }^{5}$
}

\author{
${ }^{1}$ Free Standing of Microorganism Biology, Faculty of Agriculture and Biology, \\ Warsaw University of Life Sciences - SGGW, Nowoursynowska 159 St, 02-776 Warsaw, Poland \\ ${ }^{2}$ The Board of Amelioration and Water Facilities Pomeranian Voivodeship in Gdańsk, \\ Sucha 12 St, 80-531 Gdańsk, Poland \\ ${ }^{3}$ Department of Plant Physiology, Faculty of Agriculture and Biology, Warsaw University of Life Sciences SGGW, \\ Nowoursynowska 159 St, 02-776 Warsaw, Poland \\ ${ }^{4}$ Department of Occupational Safety and Health, Faculty of Civil Safety Engineering, \\ The Main School of Fire Service, Słowackiego 52/54 St, 01-629 Warsaw, Poland \\ ${ }^{5}$ Department of Grassland Farming, Institute of Technology and Life Sciences, \\ Falenty, Hrabska 3 St, 05-090 Raszyn, Poland
}

Received: 13 October 2017 / Accepted: 22 November 2017

\begin{abstract}
Sewage sludge and phosphogypsum are by-products of wastewater treatment and phosphorus fertiliser production, respectively. Considering all known methods of their management, it seems rational to use these waste products in agriculture. While assimilating nutrients contained in sewage sludge or phosphogypsum, agricultural crops contribute to the recycling of these otherwise noxious materials. The objective of this study was to identify the effect of fertilization with sewage sludge and with phosphogypsum on selected physiological parameters that determine the efficiency of the photosynthetic apparatus in Cannabis sativa L. Field tests were conducted on three varieties of Cannabis sativa: Białobrzeskie, Tygra and Beniko. Plots were fertilized with sewage sludge as an equivalent of nitrogen nutrition in a dose of $170 \mathrm{~kg} \mathrm{~N} \cdot \mathrm{ha}^{-1}$ and with phosphogypsum applied in three doses: 100, 500 and 1000 $\mathrm{kg} \cdot \mathrm{ha}^{-1}$. The plants were subjected to physiological assays (relative content of chlorophyll and leaf area index) on three dates in 2014: 29 June (early development stage), 26 July (full development) and 20 September (final development stage). The study discusses the effect of fertilization with sewage sludge and phosphogypsum on the efficiency of the photosynthetic apparatus in Cannabis sativa.
\end{abstract}

Key words: chlorophyll, energy crop, Leaf Area Index, sewage sludge, Cannabis sativa varieties.

\section{Introduction}

The continuous growth of the human population, along with industrial development, entails the production of increasing mass of waste, including sewage sludge and phosphogypsum, which are becoming an increasingly serious problem. Attempts to return the nutrients accumulated in sewage sludge into the soil seem justifiable, both in terms of economy as well as from the point of view of preserving and restoring the ecological balance in nature. The mineral and organic composition of sewage sludge is similar to that of soil organic matter, i.e. humus (Bączalska, 1998). This 
facilitates the utilization of sewage sludge for natural purposes, including agricultural ones. Sewage sludge intended for non-industrial use must meet certain criteria regarding its chemical composition and sanitary status. Restrictions are imposed, for example, on the content of heavy metals, due to their toxic impact on living organisms and potential bioaccumulation (Bień, 2002). Phosphogypsum is a waste product produced in the production of phosphorus fertilizers, which is used in many industries, but owing to its content of nutrients, especially phosphorus, it can be applied for plant fertilization.

One of the objectives of the research on energy crops is to design such cultivation techniques that would ensure the highest possible biomass increases. Two groups of technologies can be distinguished. One comprises traditional solutions where nitrogen and phosphorus are supplied from conventional sources. The other one involves utilization of burdensome wastes, for instance sewage sludge and phosphogypsum.

Researchers involved in studies of energy crops are now paying more attention to Cannabis sativa L., a plant native to Asia that belongs to the Cannabaceae family. Cannabis sativa can be cultivated in temperate climate. During its growth, Cannabis sativa needs a total rainfall of 200-300 mm and due to the well-developed root system, the plant is tolerant to short periods of drought (Grabowska \& Koziara, 2001). The plant does not require plant protection measures as it is resistant to diseases and pest infestation. It can grow up to $3 \mathrm{~m}$ in height and the biomass yield reaches around 10-15 tha ${ }^{-1}$ (Venturi et al., 2007).

The objective of this study was to identify the effect of fertilization with sewage sludge and phosphogypsum on selected physiological parameters that determine the efficiency of the photosynthetic apparatus of Cannabis sativa $\mathrm{L}$.

It additional, it has been assumed that sewage sludge and phosphogypsum application enhances the photosynthetic performance of Cannabis sativa L. However, this effect differs between various varieties.

\section{Study area}

A two-factor field experiment with three replications was conducted at the Mazovian Agricultural Advisory Centre in Poświętne. A single plot covered $3 \mathrm{~m}^{2}$. In order to maximize the yield, $60 \mathrm{kgha}^{-1}$ of seeds were sown. Three varieties of Cannabis sativa L. were tested: Białobrzeskie, Tygra and Beniko. The plots were fertilized at the beginning of the plant's growing season with a nitrogen dose of $170 \mathrm{~kg} \mathrm{~N} \cdot \mathrm{ha}^{-1}$ (Act on Fertilizers and Fertilization, 2000). The following fertilization treatments were tested:

1. Control, without fertilization ("0"),

2. Sewage sludge fertilization ("OŚ”),
3. Fertilization with sewage sludge and with phospho-

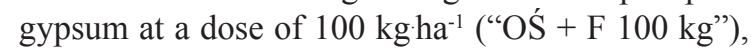

4. Fertilization with sewage sludge and with phosphogypsum at a dose of $500 \mathrm{~kg} \cdot \mathrm{ha}^{-1}$ ("OŚ + F $500 \mathrm{~kg}$ "),

5. Fertilization with sewage sludge and with phosphogypsum at a dose of $1000 \mathrm{~kg} \cdot \mathrm{ha}^{-1}$ ("OŚ + F 1000 kg").

Sewage sludge originated from the municipal wastewater treatment plant in Płońsk and met the requirements established for materials used in farming, both in terms of the content of heavy metals as well as the sanitary and hygienic condition related to the presence of eggs of intestinal parasites and bacteria of the genus Salmonella. Phosphogypsum was obtained from Grupa Azoty Zakłady Chemiczne "Police" S.A. (Police S.A. Chemical Plant in Police that belongs to the "Azoty" Group).

\section{Material and methods}

Measurements of physiological parameters characterizing the photosynthetic apparatus of Cannabis sativa L. were taken in 2014 on three dates: 29 June (early growth stage), 26 July (full development stage) and 20 September (final development stage). The following were considered as indicators of the physiological activity of the above apparatus:

- relative content of chlorophyll, measured with a Minolta SPAD 502 Meter (Konica Minolta, Japan),

- Leaf Area Index (LAI), determined with the use of a LAI 2000 meter (LI-COR, Lincoln, NE, USA).

The obtained values were global ones, measured for the entire plot cropped with plants. The LAI assays were repeated three times for each combination. The chlorophyll content was determined in ten randomly selected leaves of plants from each fertilization variant.

The results were submitted to analysis of variance. In order to determine the significance of differences between the values of the analysed parameters obtained from the different fertilization treatments, Tukey's test was applied (at a significance level of $\alpha=0.05$ ). Homogeneous groups were marked in diagrams with capital letters.

\section{Results and discussion}

Generally, the highest variation of both measured parameters i.e. chlorophyll content and Leaf Area Index (LAI) was observed in Tygra variety, while Białobrzeskie and Beniko varieties showed less variation (Figs 1-6).

The highest values of the relative chlorophyll content in leaves of Cannabis sativa variety Białobrzeskie were recorded in June and July (Fig. 1). In September, these values were considerably lower. The highest value of this 
parameter in the early phase of the experiment (29 June 2014) was observed in plants from the "OŚ + F $500 \mathrm{~kg}$ " fertilization treatment. On the other two dates of the assays, the stimulating effect of fertilization on the analysed parameter was the strongest in the fertilization treatment "OŚ +F $100 \mathrm{~kg}$ ". The lowest values of the relative chlorophyll content in June and July were noticed in the " 0 " treatment, while in September - in the "OŚ + F $1000 \mathrm{~kg}$ " variant.

Figure 2 illustrates changes over the growing season in the relative chlorophyll content in leaves of Cannabis sativa variety Tygra. The highest values of this parameter were recorded on the first two dates of the assays, while

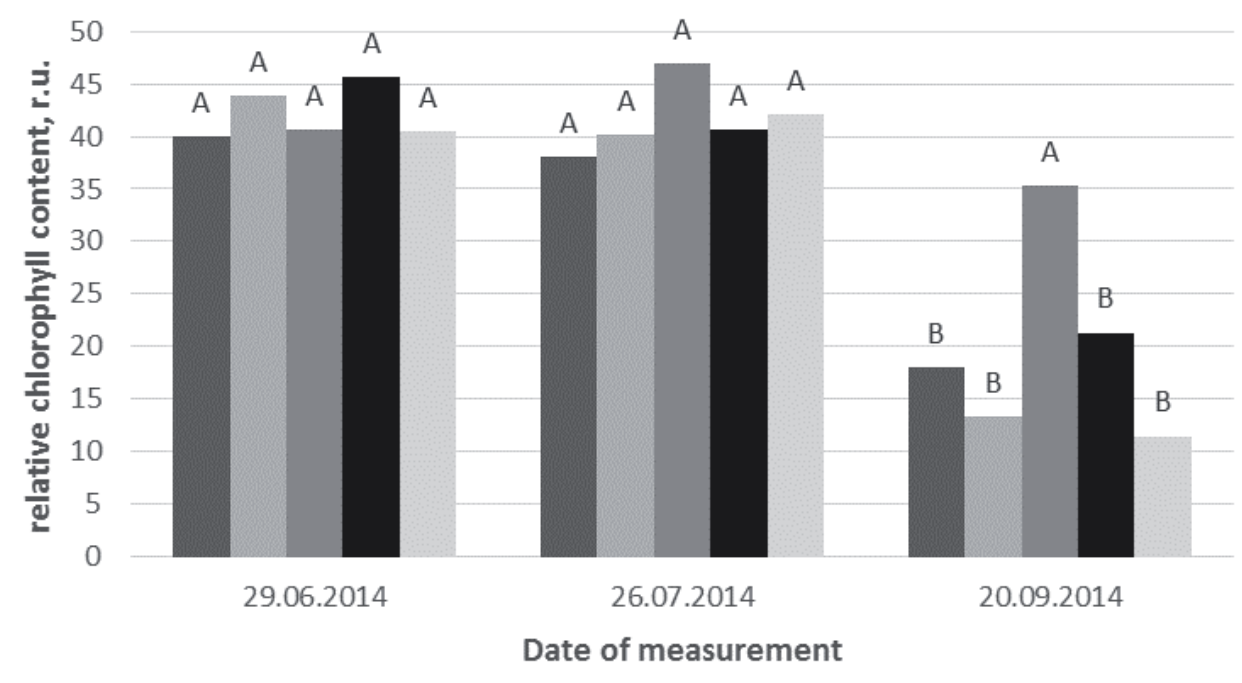

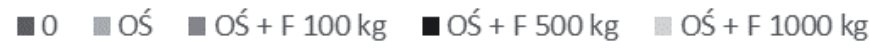

Figure 1. Seasonal changes of the relative chlorophyll content in leaves of Cannabis sativa L. Białobrzeskie variety fertilized with sewage sludge and phosphogypsum. Homogeneous groups were marked in diagrams with capital letters

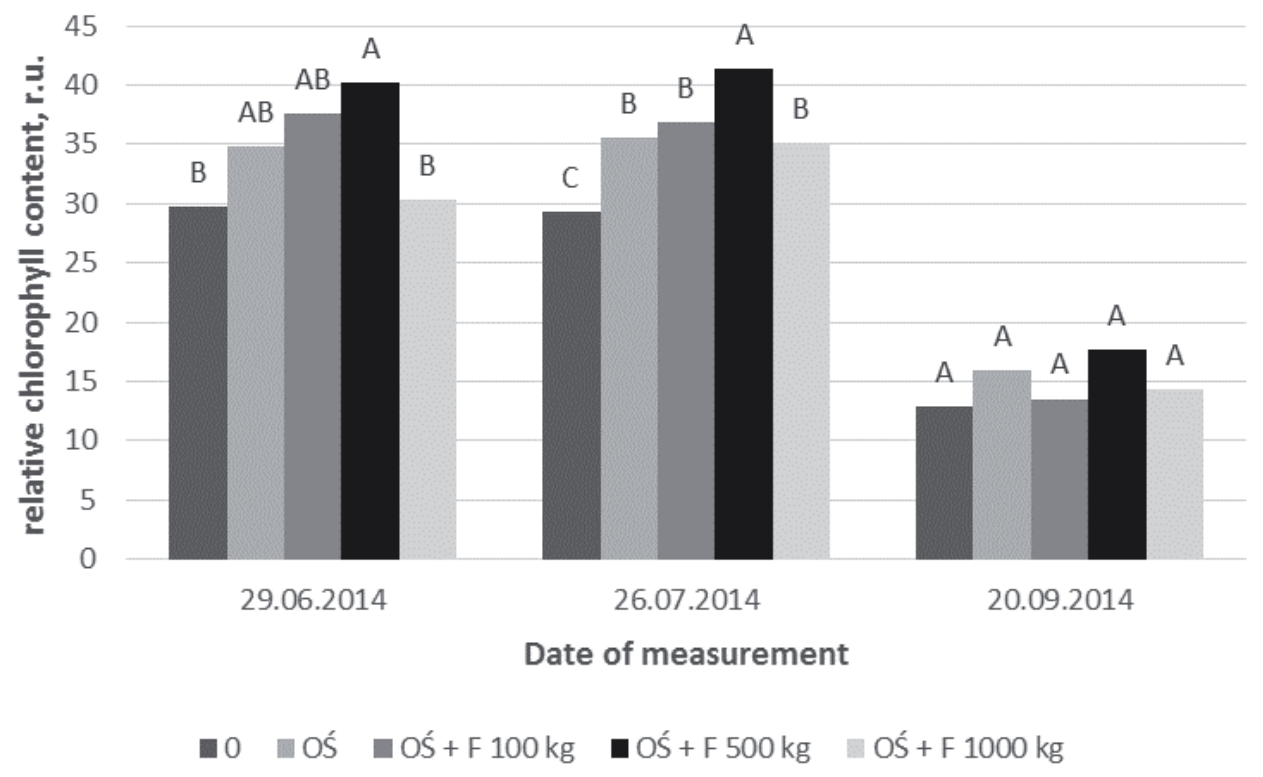

Figure 2. Seasonal changes of the relative chlorophyll content in leaves of Cannabis sativa L. Tygra variety fertilized with sewage sludge and phosphogypsum 
the lowest ones - in September. Throughout the whole research period, the highest chlorophyll content was noted in leaves from the "OŚ + F $500 \mathrm{~kg}$ " combination, while the lowest ones in leaves from the " 0 " fertilization variant.

Changes in the relative chlorophyll content in leaves of Cannabis sativa variety Beniko for the whole growing season are presented in Figure 3. The highest values of the above parameter were observed in June, while the lowest ones in September. In June and July, the stimulating effect of fertilization on the content of chlorophyll was the highest in the "OŚ + F $100 \mathrm{~kg}$ " treatment, while in September the "OŚ + F $1000 \mathrm{~kg}$ " fertilization variant proved to be the most efficient in this respect. The lowest values of the relative chlorophyll content in the whole research period, as in the case of the variety Tygra, were recorded for plants under the " 0 " fertilization variant.

The highest values of the Leaf Area Index (LAI) for Cannabis sativa variety Białobrzeskie were observed in June and July, while the lowest ones in September (Fig. 4). During the early (29.06) and final (20.09) phase of the experiment, the highest LAI values were recorded for plants growing in the "OŚ" and "OŚ + F $100 \mathrm{~kg}$ " variant, while the lowest ones by plants with no fertilization (the " 0 " variant). The above relationship was not observed in July when the highest LAI values were recorded for plants under the " 0 " treatment and the lowest ones for plants growing in the "OŚ" combination.

Changes in the LAI values for Cannabis sativa variety Tygra throughout the growing season are shown in Figure 5 . The lowest values of this parameter were noted on the first two dates of the measurements, while the lowest ones were recorded at the end of the plant development. Over the entire period, the lowest LAI values were noted for plants growing in the " 0 " fertilization variant. On the other hand, the highest values were observed for plants from the "OŚ" variant in June and September, and for plants from the "OŚ + F $100 \mathrm{~kg}$ " combination in July.

The highest LAI values for Cannabis sativa variety Beniko were recorded on the first two dates of measurements, while the lowest ones in September (Fig. 6). In June and July, the stimulating effect of fertilization on the analysed parameter was the strongest in the case of the "OŚ + F $1000 \mathrm{~kg}$ " fertilization treatment, but in September the "OŚ + F $500 \mathrm{~kg}$ " combination produced the best stimulating impact. Over the whole growing season, the lowest LAI values were noted for plants from the " 0 " variant.

Summarizing, fertilization of the three Cannabis sativa varieties selected for our experiment (Białobrzeskie, Tygra, Beniko) with sewage sludge and phosphogypsum had a relatively positive effect on the content of chlorophyll in plant leaves. Fertilization with sewage sludge and phosphogypsum at a dose of $500 \mathrm{~kg} \cdot \mathrm{ha}^{-1}$ ("OŚ + F 500 kg") showed the best results. Moreover, an increase in the analysed value was observed in the summer period. This is consistent with the results of the study reported by Augustynowicz et al. (2008).

Regarding the Leaf Area Index (LAI) measured for the whole plots, the varied fertilization applied in our tests positively affected the values of this magnitude. However, similar values were obtained when the plots were fertilized

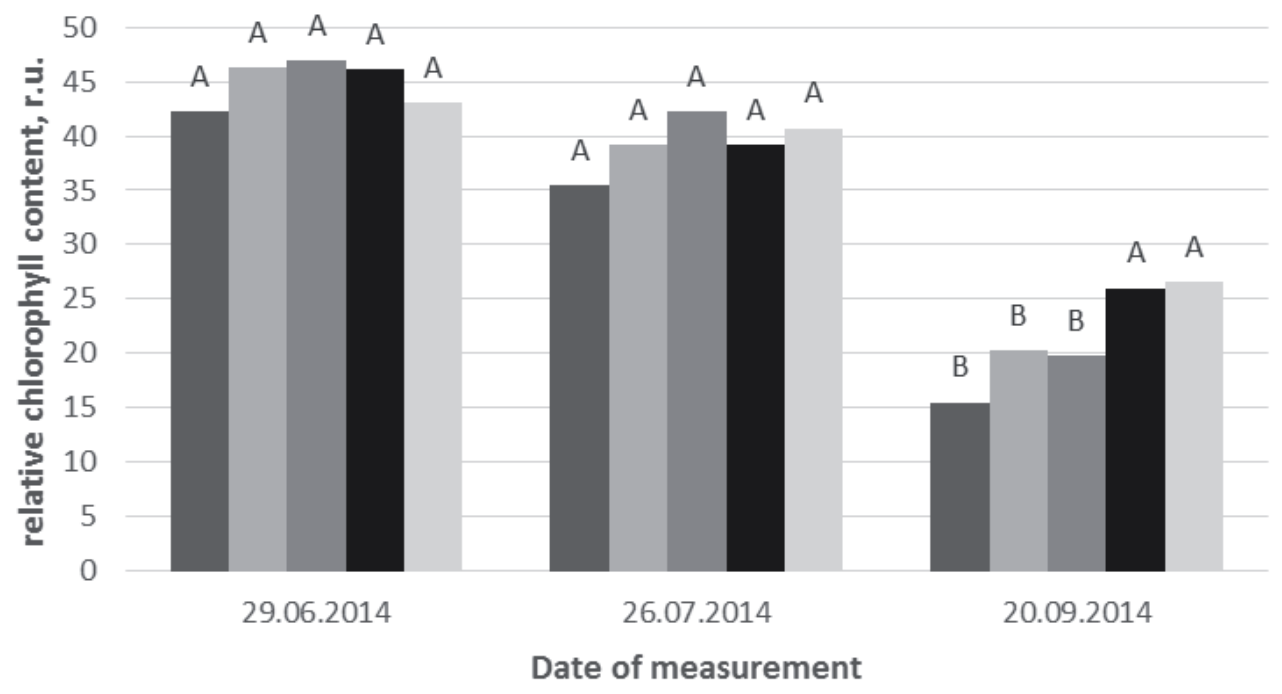

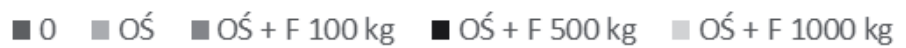

Figure 3. Seasonal changes of the relative chlorophyll content in leaves of Cannabis sativa L. Beniko variety fertilized with sewage sludge and phosphogypsum 
with sewage sludge alone or in combination with phosphogypsum in the case of the Beniko variety. This confirm that plants can benefit from the applied fertilizers, but this will depend on the variety. It should be noted here that the decrease in LAI values in the third period of our measurements was due to the canopy senescence.

Our study suggests that the application of sewage sludge alone or in combination with phosphogypsum can enhance the photosynthetic productivity of Cannabis sativa plants by increasing the chlorophyll content in the leaves and by increasing the assimilation surface (Kalaji et al., 2017). It seems that the differences in the chlorophyll content and LAI values between the three tested varieties of Cannabis sativa result from the fact that the variety Tigra has the lower chlorophyll content and the highest LAI values under control conditions and could benefit more from the

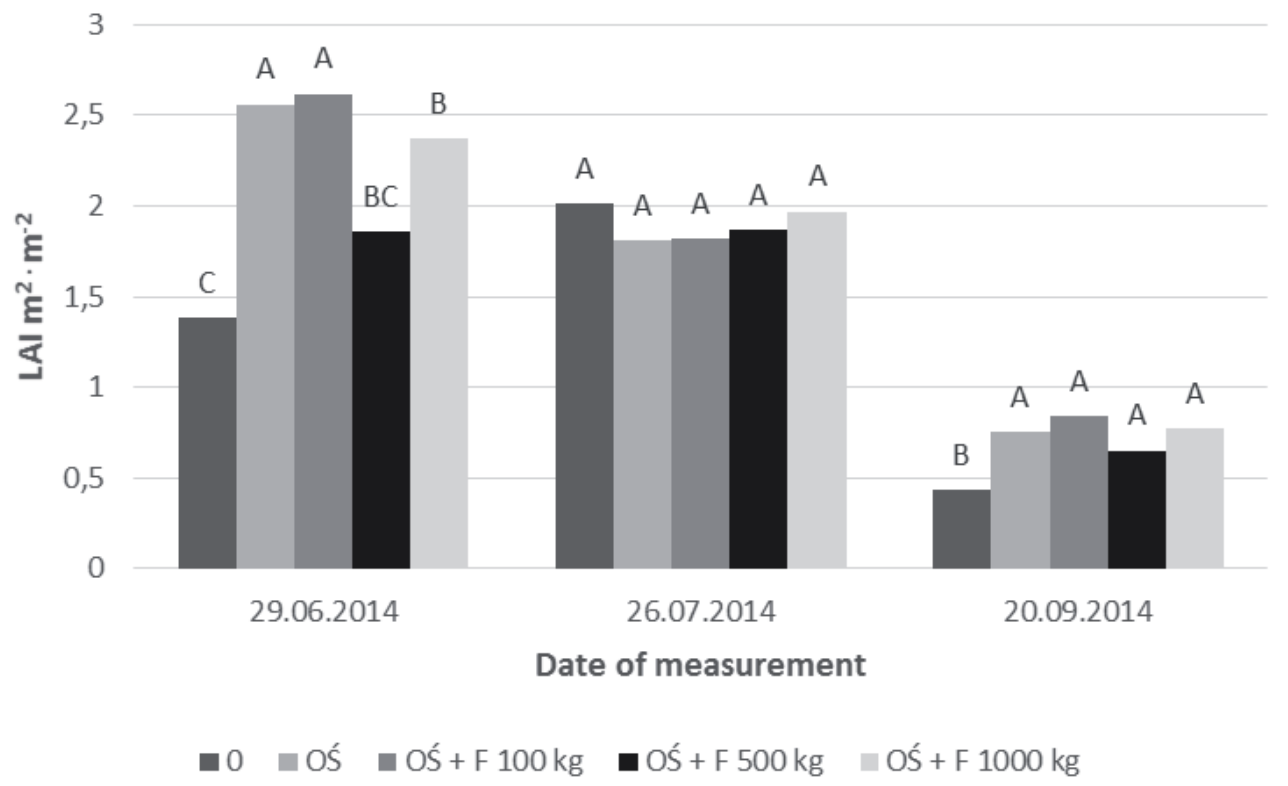

Figure 4. Seasonal changes of Leaf Area Index (LAI) of Cannabis sativa L. Białobrzeskie variety fertilized with sewage sludge and phosphogypsum

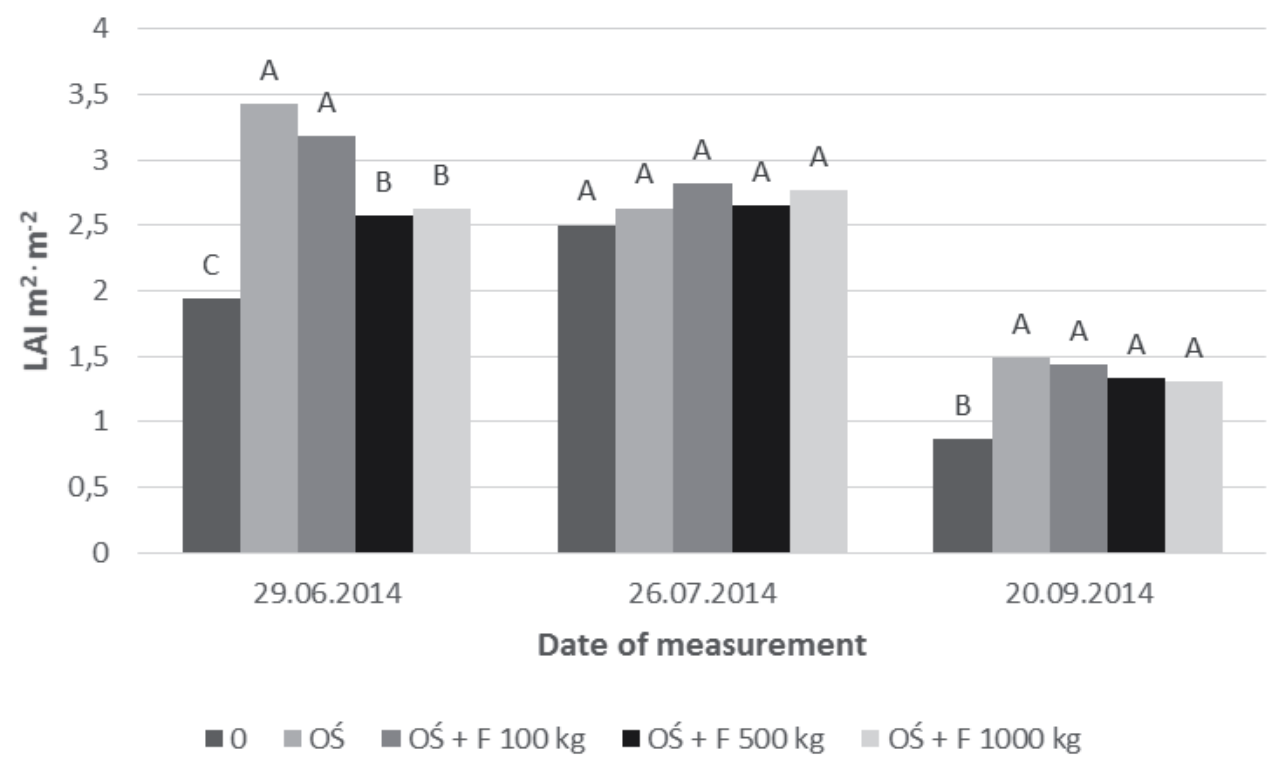

Figure 5. Seasonal changes of Leaf Area Index (LAI) of Cannabis sativa L. Tygra variety fertilized with sewage sludge and phosphogypsum 


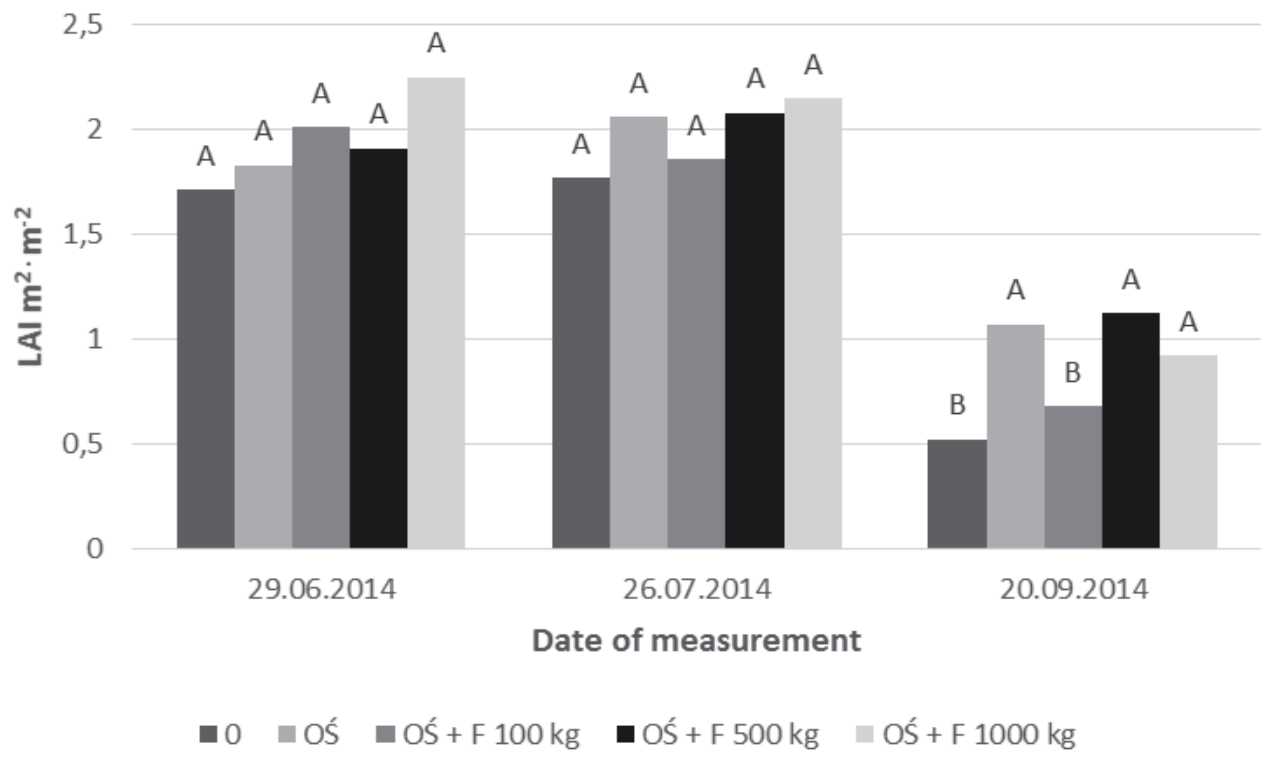

Figure 6. Seasonal changes of Leaf Area Index (LAI) of Cannabis sativa L. Beniko variety fertilized with sewage sludge and phosphogypsum

application of sewage sludge fertilization and phosphogypsum than the other tested verities. This can be explained by the fact that a larger assimilation surface can provide more intensive absorption of water and minerals (Dąbrowski et al., 2013) available in the applied sewage sludge and phosphogypsum. Therefore, the plant canopy and physiological features can determine how much of the added fertilizers is used. These results are in agreement with the results obtained by Feng et al. (2016) and Daughtry et al. (2000).

\section{Conclusion}

The following conclusions can be drawn from the results and discussion presented in this paper:

1. The use of sewage sludge (without or in combination with phosphogypsum) improves the photosynthetic performance of Cannabis sativa plants. However, this effect varies between different varieties.

2. Varieties with a higher Leaf Area Index (LAI) can use the applied fertilizers more efficiently compared to those with low LAI values, due higher absorption of water and nutrients.

3. We recommend using the two techniques presented in this study (LAI and chlorophyll content measurements) as non-invasive and reliable tools for assessing the effect of various fertilisers that can improve the performance of Cannabis sativa plants under field conditions.

\section{References}

Augustynowicz J., Pietkiewicz S., Kalaji M. \& Russel S., 2008, Wpływ preparatów EM na wybrane parametry fizjologiczne i produkcję biomasy przez rośliny energetyczne na przykładzie słonecznika bulwiastego (topinambura) [Effect of EM preparations on selected physiological parameters and biomass production of energy crops: A case study of the Jerusalem artichoke], [in:] B. Wiśniowska-Kielian (ed.), Wielokierunkowość badań w rolnictwie i leśnictwie [Multidirectional Research in Agriculture and Forestry], vol. 2, Uniwersytet Rolniczy im. Hugona Kołłątaja, Kraków: 9-24.

Bączalska D., 1998, Ocena możliwości składowania skratek pochodzących z Grupowej Oczyszczalni Ścieków we Włocławku na miejskim wysypisku komunalnym [An evaluation of possibilities of disposal of the solid waste from primary filtration and screening originating from the WTP in Włocławek on a municipal landfill], [in:] Osady ściekowe w praktyce [Sewage Sludge in Practice], 7. Konf. Nauk.-Techn [7th Science and Technology Conference in Częstochowa-Ustroń], Częstochowa-Ustroń. Wydawnictwo Politechniki Częstochowskiej, Częstochowa: 18-31.

Bień J.B., 2002, Osady ściekowe. Teoria i Praktyka [Sewage sludge. Theory and Practice], Wydawnictwo Politechniki Częstochowskiej, Częstochowa: 34-56.

Daughtry C.S.T., Walthall C.L., Kim M.S., de Colstoun E.B. \& McMurtrey III, J.E., 2000, Estimating corn leaf chlorophyll concentration from leaf and canopy reflec- 
tance. Remote Sensing of Environment 74(2): 229 239. (http://www.sciencedirect.corn/science/article/pii/ S0034425700001139).

Dąbrowski P., Pawluśkiewicz B., Kalaji M.H. \& Baczewska A.H., 2013, The effect of light availability on leaf area index, biomass production and plant species composition of park grasslands in Warsaw. Plant, Soil and Environment 59(12): 543-548.

Feng G., Luo H., Zhang Y., Gou L., Yao Y., Lin Y. \& Zhang W., 2016, Relationship between plant canopy characteristics and photosynthetic productivity in diverse cultivars of cotton (Gossypium hirsutum L.). The Crop Journal 4: 499-508.

Grabowska L. \& Koziara W., 2001, Wpływ temperatury i opadów na plonowanie konopi włóknistych odm. Białobrzeskie [Effect of temperature and precipitation on yields of the Cannabis sativa variety Białobrzeskie]. Natural Fibres, vol. XXXXV, Poznań: 32-46.
Kalaji H.M., Dąbrowski P., Cetner M.D., Samborska I.A., Łukasik I., Brestic M., Zivcak M., Horaczek T., Mojski J., Kociel H. \& Balaji P.M., 2017, A comparison between different chlorophyll content meters under nutrient deficiency conditions. Journal of Plant Nutrition 40(7): 1024-1034. [DOI:10.1080/01904167.2016.1263 323].

Ustawa z dnia 26 lipca 2000 r. o nawozach i nawożeniu (Dz.U. RP 2000, nr 89, poz. 991, Kanc. Prezesa Rady Min.) [Act on Fertilizers and Fertilization of 26 July 2000 (Journal of Laws RP of 2000, No. 89, item 991, Chancellery of the Prime Minister)], 2000, Warszawa.

Venturi P., Amaducci S., Amaducci M.T. \& Venturi G., 2007, Interaction Between Agronomic and Mechanical Factors for Fiber Crops Harvesting: Italian ResultsNote II. Hemp. Journal of Natural Fibers 4(3): 83-97. 